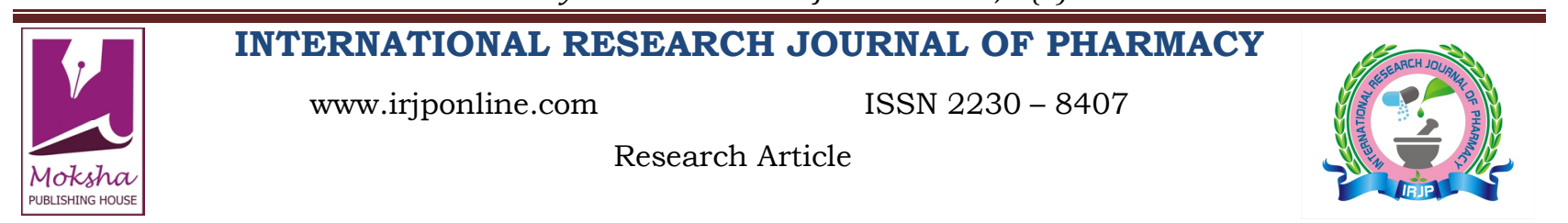

\title{
COMPARISON OF GENOTOXICITY PRODUCED BY HYDRO ALCOHOLIC EXTRACT OF CURCUMA AROMATICA SALISB, CURCUMA ZEDOARIA WITH CURCUMIN BY AMES TEST, COMET ASSAY AND MICRONUCLEUS TEST
}

Srividya A.R*1, Dhanbal S.P ${ }^{2}$, Sathish Kumar M.N ${ }^{3}$ and Vishnuvarthan V.J. ${ }^{3}$

${ }^{1}$ Department of Pharmaceutical biotechnology, JSS College of Pharmacy Udhagamandalam, Tamilnadu, India

${ }^{2}$ Department of Pharmacognosy and Phytomedicine, JSS College of Pharmacy, Udhagamandalam, Tamilnadu, India

${ }^{3}$ Department of Pharmacology, JSS College of Pharmacy, Udhagamandalam, Tamilnadu, India

*Corresponding Author Email: pharmarsrividya@yahoo.com

Article Received on: 14/03/13 Revised on: 09/04/13 Approved for publication: 01/05/13

DOI: $10.7897 / 2230-8407.04625$

IRJP is an official publication of Moksha Publishing House. Website: www.mokshaph.com

(C) All rights reserved.

\section{ABSTRACT}

This paper deals with the comparison of genotoxicity produced by the hydro alcoholic extract of Curcuma aromatica salisb and Curcuma zedoaria (christm) rosecoe with curcumin by Ames test, comet assay and Micronucleus test. Curcuma aromatica and Curcuma Zedoaria belongs to the family Zingiberaceae. In the presence of metabolic activation factor (S9), the revertant colonies were found to be more in the case of TA98 and TA 100 strains. When compared to positive control the numbers of revertant colonies were found to be more or less equivalent to negative control which confirmed the absence of genotoxic effect of test compounds. In the comet assay, among the three tested compounds, curcumin was found to be more genotoxic in nature when compared by Curcuma aromatica, Curcuma zedoaria. The damage of the cells was found to be more in the presence of metabolic activation factor than the absence of metabolic activation factor. This confirmed that the phytoconstituents are not genotoxic in nature but their metabolites that are formed in the presence of metabolic activation factor is mainly responsible for their genotoxic effect. In the Micronucleus test, when compared to the positive control (Methyl methane sulfonate at the concentration of $50 \mu \mathrm{g} / \mathrm{ml}$ ), all the test compounds such as hydro alcoholic extract of Curcuma aromatica, Curcuma zedoaria, and Curcumin at the concentration of $50 \mu \mathrm{g} / \mathrm{ml}$ showed less toxicity to HEp- 2 cells. These results might either due to the presence of low concentration of curcumin in the extracts or due to the presence of other phytoconsituents that are present in the extract.

Keywords: Curcuma aromatica, Curcuma zedoaria, Ames test, comet assay, micronucleus test, Curcumin.

\section{INTRODUCTION}

The potential consequence of genetic damage that a cell can incur is called genotoxicity. In all the cells and organism the damage response mechanism is available. Genotoxins are the substances which causes the genotoxicity in a cell ${ }^{1}$. In India majority of the population uses traditional natural preparations from the plant material for the treatment of various diseases and hence it is necessary to assess clastogenic potential of the traditional plant extract when associated with other substances. Along with the increase in genotoxicity; risk of developing cancer increases ${ }^{2}$. In everyday life, usage of antimutagens and anticarcinogens are suggested and most effective procedure for preventing human cancer and genetic diseases. In medicinal plants, a bioactive component acts as a strategy to block or reverse carcinogens at the early stages. In cancer treatment medicinal plants were considered effective and inexpensive. Herbal plants were proved antimutagenic agents and helps in inhibiting carcinogenic effect of some chemical mutagens, herbal plants were proved as an antimutagenic agent. Currently there is enormous interest in developing new plant based pharmaceutical products ${ }^{3}$. Curcuma species are perennial herbs belonging to the family Zingiberaceae. From that species Curcuma aromatica and Curcuma zedoaria has been selected for this study. Traditionally Curcuma aromatica rhizome is used as tonic, carminatives, astringent, bitters, in sprain and in snake bite and also for treating skin eruption due to infection. $\alpha$ - Curcumene and $\beta$ Curcumene, $d$ and $p$ methoxy cinnamic acid are present in this rhizome. Curcumin is the coloring matter in these rhizomes ${ }^{4}$. Traditional uses of Curcuma zedoaria rhizome are Carminative, stomachic, gastrointestinal stimulant, diuretic, expectorant demulcent, rubifacient. It is also used in flatulence and dyspepsia. For checking leucorrhoea discharge fresh roots are used and it is also used as blood purifier. This rhizome is used in the treatment of Goiter according to the information that is present in the Ayurvedic pharmacopoeia of India. Number of terpenoids including Curcumin, Curcumenone, Curdione, Curcumenol, Curzerenone, Furanogermenone, Germacrone, Germacrone epoxide a volatile oil (1.0-1.5) resembling ginger oil and starch $(50 \%)$ are present in the dried rhizome. It is also used as an antitumor, antiallergenic and antimicrobial agent ${ }^{5,6}$. Curcumin which is an active component is present in the range of $2-5 \%$. It is an orange crystalline powder which is insoluble in water. For centuries, Curcumin has been consumed as a dietary spice at dose up to $100 \mathrm{mg} /$ day. The biological activities that are reported for Curcumin are blood cholesterol reduction, LDL peroxidation prevention, platelet aggregation inhibition, thrombosis suppression, Myocardial infarction curing, type -II diabetes associated symptoms suppression, rheumatoid arthritis, Multiple Sclerosis, Alzheimer's disease, human immune deficiency virus (HIV) replication inhibition, wound healing enhancement, liver protection from injury, bile secretion increase, cataract formation prevention, Protects from Pulmonary toxicity and fibrosis prevention. It also possesses anti-leshmaniasis anti atherosclerotic and anticancer activities $^{2.4}$. It proved to be a powerful antioxidant ${ }^{7}$. We have performed the genotoxicity studies of the same plants by various methods such as chromosomal aberration studies ${ }^{2}$, DNA sugar damage test, SOS Chromotest, plasmid nicking assay and sequential analysis ${ }^{4}$. Due to the diversity of the end points it is clear that the potential genotoxicity or mutagenicity of a compound cannot be assessed by a single assay system ${ }^{8}$. By any single genotoxic test procedure the mutagenic potential of an agent can't be reliably determined because currently available mutagenicity assay have their own strength and weakness ${ }^{9}$. In this paper we dealt with the 
genotoxic activities of hydro alcoholic extract of Curcuma aromatica, Curcuma zedoaria and Curcumin by Ames reversion assay, Micronucleus test and Comet assay.

\section{MATERIALS AND METHODS}

The rhizomes of Curcuma aromatica salisb and Curcuma zedoaria (Christm) Roscoe are purchased from PSS Herbs Pvt. Ltd, Kerala, India and authenticated by Dr. S. Rajan, Botanist, Udhagamandalam, Tamilnadu, India. Curcumin was sponsored by Sami Labs Pvt. Ltd, Bangalore, India. The rhizomes of Curcuma aromatica salisb, Curcuma zedoaria (Christm) Roscoe are shade dried; milled and coarse powder is separated. $50 \%$ hydro alcoholic extracts are prepared for Curcuma aromatica salisb, Curcuma zedoaria (Christm) Roscoe rhizomes and these prepared extracts are used for antioxidant and genotoxicity studies.

\section{Ames test}

It is the method for evaluating the mutagenic properties of extracts by bacterial reverse mutation assay using various tester strains. This test was carried with certain modification according to Meshram et al 1992. TA 98, TA 100 of Salmonella typhimurium are the histidine deficient (His') mutant tester strain. The bacterial reverse mutation test uses amino acid requiring strains of Salmonella typhimurium to detect the point mutation which involves substitution, addition or deletion of one or few DNA base pairs. The principle of this bacterial reverse mutation test is that it detects mutation which revert mutation present in the test strains and restore the functional capability of the bacteria to synthesize an essential amino acid. The revertant bacteria are detected by their ability to grow in the absence of essential amino acids required by the parent tester strains. TA-98 strain is used to identify the frame shift mutation. TA-100 strain is used to identify the base pair substitution. These mutant strains are obtained from Amala Cancer Institute, Thirussur, India. On receipt these strains are labeled in in-house and kept under refrigerated conditions. One loopful of microorganism is removed and inoculated into a conical flask containing nutrient broth. The inoculated flask is incubated at $37^{0} \mathrm{C}$ for about 14-18 hours to achieve a density of 1$2 \times 10^{9} \mathrm{CFU} / \mathrm{ml} .100 \mu \mathrm{l}$ of overnight culture $\left(1-2 \times 10^{9} \mathrm{CFU} / \mathrm{ml}\right)$ is used for the bacterial reverse mutation assay. Extracts is made to soluble in reverse osmosis water and $50 \mu \mathrm{g} / \mathrm{ml}$ concentrations of the extracts are prepared. Vehicle control is plated for tester strains in the presence and absence of S9 mixture. In the absence of S9 mix, 2- nitrofluorene is used as positive control for the strain TA98. In the presence of S9 mix benzo [a] pyrene is used as positive control. In the absence of S9 mix, sodium azide is used as positive control and 2- aminoanthracene is used as positive control in the presence of S9 mix for the strain TA-100. The tester strain does not possess enzymes systems which are present in mammals to metabolize pro- mutagens to active electrophilic metabolite capable of reacting with DNA. Sometimes these pro-mutagens interact with mammalian enzyme system and yield mutagenic metabolite. Hence it is necessary to add external metabolic activation system that is post mitochondrial fraction (S9). Presence / absence of genotoxicity is detectable, based up on the number of revert ant colonies per plate ${ }^{10,11}$.

\section{Procedure}

The revert ant colonies are counted, their mean and standard deviation is calculated. Positive result is defined as a dose dependent increase or a reproducible increase at one or more concentrations in the number of revert ant colonies per plate in at least one strain with or without metabolic activation system. Bacterial culture is inoculated from the frozen cultures to $10 \mathrm{ml}$ of nutrient broth and incubated at $37^{\circ} \mathrm{C}$ for 12 hours to obtain approximately $1 \times 10^{9}$ cells $/ \mathrm{ml}$. To $2 \mathrm{ml}$ of top agar medium containing $0.6 \%$ agar, $0.6 \% \mathrm{NaCl}$ and traces of histidine $(21 \mu \mathrm{g} / \mathrm{ml})$ and biotin $(24.4 \mu \mathrm{g} / \mathrm{ml})$ and $0.1 \mathrm{ml}$ of cell suspension, $0.5 \mathrm{ml}$ of extract solution $(50 \mu \mathrm{l} / \mathrm{ml}$ concentration) are added. Solvent control, positive controls, S9 mix $(0.5 / \mathrm{ml}$ plate, $10 \% \mathrm{v} / \mathrm{v}$ ) are also added on the top of the nutrient agar medium. Experiments are carried out in triplicate for each tested compounds. Then the plates are incubated upside down for 2 days at $37^{\circ} \mathrm{C}$ and the resulting histidine revertant are counted.

\section{Comet assay}

Comet assay was being carried out with the human blood. $4 \mathrm{ml}$ of heparinized whole blood is mixed with $3 \mathrm{ml}$ of RPMI medium. The medium is centrifuged at $4^{0} \mathrm{C}$ for 15 minutes at $1600 \mathrm{rpm}$. Buffy coat containing the lymphocytes is washed in RPMI 1640 medium. Then the cells are resuspended in RPMI 1640 medium and the concentration of the cells is adjusted in such a way that $1 \mathrm{ml}$ should contain $10^{6}$ cells approximately. By Trypan blue staining method the cell viability is counted and checked. The cells that exceeded $90 \%$ viability are used in genotoxicity assay. Under alkaline method the comet assay was carried out according to the method of Singh et al. 1988 with slight modification. $0.9 \mathrm{ml}$ of the cell suspension is mixed with $0.1 \mathrm{ml}$ of the Curcuma aromatica, Curcuma zedoaria and Curcumin. And then it is incubated at $37^{\circ} \mathrm{C}$ for 30 minutes. By centrifugation, the cells are collected and suspended in low melting point agarose in the phosphate buffer saline with the pH7.4. The cells are immediately pipetted onto a glass slide which was already coated with a layer of normal melting point agarose. Then the glass slide is kept at $4^{0} \mathrm{C}$ for 5 minutes to get solidify. Over this agarose layer melting agarose is added as the third layer and the slide was kept at $4^{0} \mathrm{C}$ for 5 minutes. For about an hour the slides are immerged in lysing solution $(2.5 \mathrm{M} \mathrm{NaCl}$, $10 \mathrm{mM} \mathrm{Na}_{2}$ EDTA, $10 \mathrm{nM}$ Tris $\mathrm{pH} \mathrm{10,1 \%} \mathrm{Sodium} \mathrm{sarcocinate,}$ $1 \%$ Triton $\mathrm{X}-100$ and $10 \%$ dimethyl sulfoxide) at $4^{0} \mathrm{C}$. The slides are placed in a horizontal gel electrophoresis. Using $25 \mathrm{~V}$ and $300 \mathrm{~mA}$ electrophoresis is performed for 20 minutes. With the neutralizing buffer $(400 \mathrm{mM}$, Tris Buffer $\mathrm{pH} 7.5)$ the slides are washed and then stained with ethidium bromide. Using a fluorescence microscope cells are visualized. Using the computerized image analysis system the date are analyzed. By the ratio of tail to head length the extend of DNA damages is ascertained and scored as follows:- $<5.0 \%$ -No damage, $5.1-20.0 \%$ - Low damage, 20.1-40.0\%medium damage, 40.1-95.0\%- high damage, $>95.1 \%$ complete damage. ${ }^{12-14}$

\section{Micronucleus assay}

Micronucleus assay was carried out by using Human larynx epidemoid carcinoma cells (HEp-2) cells which was are obtained from the National cell culture, Pune, India. In $25 \mathrm{~cm}^{2}$ flasks containing $5 \mathrm{ml}$ of complete medium, HEp-2 cells are seeded and maintained as monolayer growing at $37^{\circ} \mathrm{C} .10 \%$ fetal calf serum is supplemented to the culture medium along with $2.38 \mathrm{mg} / \mathrm{ml}$ of HEPES and $0.01 \mathrm{mg} / \mathrm{ml}$ of Streptomycin and $0.005 \mathrm{mg} / \mathrm{ml}$ of Penicillin. After thawing $10^{6}$ cells are seeded in several flasks in complete medium for 48 hours till the completion of two cycles. The cells are washed with PBS 
and treated with the test compounds such as hydro alcoholic extract of Curcuma aromatica, Curcuma zedoaria and Curcumin at $50 \mu \mathrm{g} / \mathrm{ml}$ concentration in serum free medium over a period of 2 hours. The cells that were treated with MMS (Methyl methane sulfonate) at the concentration of $100 \mu \mathrm{g} / \mathrm{ml}$ are used as positive control. The cells that did not receive any drug are used as negative control. To evaluate the mutagenicity, the cells are washed twice with $5.0 \mathrm{ml}$ of PBS (pH7.4). To block cytokinesis and to yield binucleated cells, to a fresh complete culture medium Cytochalasin- B is added at the concentration of $3 \mu \mathrm{g} / \mathrm{ml}$ and kept for 28 hours. The cells are rinsed twice with $5 \mathrm{ml}$ of PBS. After trypsinisation the cells are centrifuged for 5 minutes at 900rpm. In ice- cold hypotonic solution $(1 \%$ sodium citrate + one drop of $10 \%$ formaldehyde) the pellets are resuspended and carefully homogenized with Pasteur pipette. Homogenized cell suspension is once again centrifuged for 5minutes at $900 \mathrm{rpm}$. The pellets are resuspended in methanol and acetic acid in the ratio 3:1 and the cells were homogenized carefully with the Pasteur pipette. On a previously cleaned slide, the fixed cells are then dropped and covered with a film of ice cold distilled water for 5 minutes. The cells are stained in 3\% giemsa dissolved in phosphate buffer $\left(\mathrm{Na}_{2} \mathrm{HPO}_{4}-0.06 \mathrm{M}\right.$ and $\mathrm{KH}_{2} \mathrm{PO}_{4^{-}}$0.06M- $\mathrm{pH} 6.8$ ). Then the cells are washed with water, dried and kept at $4^{0} \mathrm{C}$ until it is scored. Using a microscope at 400x magnification, 2000 cells per slide is analyzed. The criteria that is followed for the identification of binucleated cells and micronuclei as follows: ${ }^{15,16}$

1. Shape should be round for both the nuclei and micronuclei.

2. When compared to the main nuclei, the micronuclei should be $1 / 3$ small.

3. The main nuclei should not touch the micronucleus.

4. The color and intensity of the micronuclei must be same as the main nuclei.

\section{RESULTS}

\section{Ames Reverse mutation assay}

In this assay, two strains were used. They are TA 98 and TA 100. TA 98 is used to determine frame shift mutation that is caused by the test compounds. TA100 is used to determine base pair substitution. Both the strains were obtained from Amala Cancer Research Institute, Thirussur, Kerala, India. To determine the frame shift mutation, in the absence of S9 factor, 2- nitrofluorene and in the presence of S9 factor Benzo[a]pyrene was used as the positive control which produced the number of revertant colonies such as $682 \pm 86$ and $510 \pm 44$ respectively at the concentration of $50 \mu \mathrm{g} / \mathrm{ml}$. In the negative control plate the revertant colonies produced were $12 \pm 1,16 \pm 2$ in the absence and presence of S9 respectively. In the presence of S9 factor revertant colonies found to decrease in the case of positive control where as for the test compounds, revert ant colonies found to increase in the presence of S9 factor.

\section{In the absence and presence of S9 factor}

Revertant colonies were found to be more at the concentration of $50 \mu \mathrm{g} / \mathrm{ml}$ for Curcuma aromatica in the absence of S9 factor $14 \pm 2$ and in the presence of S9 factor the number of revertant colonies were $18 \pm 3$. For Curcuma zedoaria, in the absence of S9 factor $10 \pm 1$ and in the presence of S9 factor the number of revertant colonies was $16 \pm 1$. The number of revert ant colonies produced by curcumin was found to be $23 \pm 1$ in the absence of S9 factor and $26 \pm 3$ in the presence of metabolic activation factor. The results are tabulated in Table 1.

\section{TA 100 Control}

To detect the base pair substitution type of mutation, in the absence of S9 factor sodium azide and in the presence of S9 factor 2- aminoanthracene were used as positive control which gave the number of revertant colonies such as $1501 \pm 132$ and $308 \pm 20$ at the concentration of $50 \mu \mathrm{g} / \mathrm{ml}$. In the negative control plates the number of revertant colonies was $14 \pm 2$ and $78 \pm 18$ in the absence and presence of S9 factor respectively.

\section{In the Absence and presence of S9 factor}

In the absence of S9 factor, the number of revertant colonies was found to be $16 \pm 3$ for Curcuma aromatica at the concentration of $50 \mu \mathrm{g} / \mathrm{ml}$. At the concentration of $50 \mu \mathrm{g} / \mathrm{ml}$ the numbers of revertant colonies were $18 \pm 1$ for Curcuma zedoaria and $25 \pm 2$ for Curcumin. In the presence of $\mathrm{S} 9$ factor the revertant colonies were $64 \pm 10$ for Curcuma aromatica at the concentration of $50 \mu \mathrm{g} / \mathrm{ml}$ respectively. At the concentration of $50 \mu \mathrm{g} / \mathrm{ml}$, the numbers of revertant colonies were $80 \pm 8$ for Curcuma zedoaria and $86 \pm 7$ for curcumin. When compared to positive control the numbers of revert ant colonies were found to be more or less equivalent to negative control which confirms the absence of genotoxic effect of test compounds. In the presence of S9 factor Benzo [a] pyrene was used as the positive control, 2- nitrofluorene was used positive control in the absence of S9 factor. The results are tabulated in Table 2.

\section{Comet assay}

In control samples $93 \pm 3$ cells were found to have no damage in the presence of metabolic activation factor where as in the absence of metabolic activation factor $97 \pm 3$ cells were found to have no damage in the control sample. At the concentration of $50 \mu \mathrm{g} / \mathrm{ml}$; In the absence of metabolic activation factor Curcuma aromatica salisb, No damage was found in $70 \pm 3$ cells, low damage was found to be in $22 \pm 5$ and medium damage was found in $8 \pm 4$ cells. In cells there was no high damage and complete damage occurred in the cells. In the cells treated with Curcuma zedoaria (Christm) Roscoe the normal cells were found to be $79 \pm 3$ cells. In $15 \pm 2$ cells low damage was observed and in $6 \pm 3$ cells medium damage was observed. In the cells treated with Curcumin, normal cells were found to be $62 \pm 4,28 \pm 3$ cells showed low damage and medium damage had occurred in $10 \pm 4$ cells.

\section{At the concentration of $50 \mu \mathrm{g} / \mathrm{ml}$}

In the presence of metabolic activation factor Curcuma aromatica salisb caused high damage in $6 \pm 5$ cells, medium damage was found in $12 \pm 3$ cells, low damage was found in $24 \pm 5$ cells and normal cells were found to be $49 \pm 2$ cells. Curcuma zedoaria (Christm) Roscoe caused high damage in $5 \pm 4$ cells, medium damage in $11 \pm 5$ cells and low damage in $30 \pm 1$ cells and normal cells were found to be $54 \pm 3$ cells. Curcumin caused complete damage in $4 \pm 3$, high damage in $8 \pm 3$ cells. It caused medium damage in $10 \pm 2$ cells and low damage in $37 \pm 2$ cells and normal cells were found to be $41 \pm 3$ cells. Among the three tested compounds, curcumin was found to be more genotoxic in nature when compared by Curcuma aromatica, Curcuma zedoaria. These results might either due to the presence of low concentration of curcumin in the extracts or due to the presence of other phytoconsituents that are present in the extract. The damage 
of the cells was found to be more in the presence of metabolic activation factor than the absence of metabolic activation factor. This confirms that the phytoconstituents are not genotoxic in nature but their metabolites that are formed in the presence of metabolic activation factor is mainly responsible for their genotoxic effect. These results are tabulated in the Table 3.

\section{Micronucleus test}

Curcuma aromatica at the concentration of $50 \mu \mathrm{g} / \mathrm{ml}$ produced the micronuclei at the rate of $12.333 \pm 2.223$, $15.666 \pm 1.778$, in the absence and presence of metabolic activation factor respectively. Curcuma zedoaria at the concentration of $50 \mu \mathrm{g} / \mathrm{ml}$ produced the micronuclei at the rate of $9.666 \pm 1.999,14.666 \pm 2.666$ in the absence and presence of metabolic activation factor respectively. Curcumin at the concentration of $50 \mu \mathrm{g} / \mathrm{ml}$ produced the micronuclei at the rate of $14.666 \pm 1.555,19.333 \pm 1.111$ in the absence and presence of metabolic activation factor respectively. Positive control (Methyl methane sulfonate) produced the micronuclei at the rate of $25.666 \pm 1.555$, $35.66 \pm 2.886$ in the presence and absence of metabolic activation factor respectively. When compared to the positive control (Methyl methane sulfonate at the concentration of $50 \mu \mathrm{g} / \mathrm{ml})$, all the test compounds such as hydro alcoholic extract of Curcuma aromatica, Curcuma zedoaria and Curcumin at the concentration of $50 \mu \mathrm{g} / \mathrm{ml}$ showed less toxicity to HEp-2 cells. The results are tabulated in Table 4.

Table 1: Ames test result for the Strain TA98

\begin{tabular}{|c|c|c|}
\hline \multirow{2}{*}{ Test compounds } & Mean \pm SEM (-S9) & Mean \pm SEM (+S9) \\
\cline { 2 - 3 } & Concentrations & Concentrations \\
\cline { 2 - 3 } & $\mathbf{5 0} \boldsymbol{\mu} \mathbf{g} / \mathbf{m l}$ & $\mathbf{5 0} \boldsymbol{\mu g} / \mathbf{m l}$ \\
\hline Positive control & $682 \pm 86$ & $510 \pm 44$ \\
\hline Negative control & $12 \pm 1$ & $16 \pm 2$ \\
\hline Curcuma aromatica salisb & $14 \pm 2$ & $18 \pm 3$ \\
\hline Curcuma zedoaria (Christm.) Roscoe & $10 \pm 1$ & $16 \pm 1$ \\
\hline Curcumin & $23 \pm 5$ & $26 \pm 3$ \\
\hline
\end{tabular}

Table 2: Ames test result for TA 100

\begin{tabular}{|c|c|c|}
\hline \multirow{2}{*}{ Test compounds } & Mean \pm SEM (-S9) & Mean \pm SEM (+S9) \\
\cline { 2 - 3 } & Concentrations & Concentrations \\
\cline { 2 - 3 } & $\mathbf{5 0} \boldsymbol{\mu \mathbf { g }} / \mathbf{m l}$ & $\mathbf{5 0} \boldsymbol{\mu g} / \mathbf{m l}$ \\
\hline Positive control & $1501 \pm 132$ & $308 \pm 20$ \\
\hline Negative control & $14 \pm 2$ & $78 \pm 18$ \\
\hline Curcuma aromatica salisb & $16 \pm 3$ & $64 \pm 10$ \\
\hline Curcuma zedoaria (Christm.) Roscoe & $18 \pm 1$ & $80 \pm 8$ \\
\hline Curcumin & $25 \pm 2$ & $86 \pm 7$ \\
\hline
\end{tabular}

Table 3: Genotoxicity of Curcuma aromatica, Curcuma zedoaria and Curcumin in human lymphocytes in the comet assay

\begin{tabular}{|c|c|c|c|c|c|}
\hline \multirow[b]{2}{*}{ Sample } & \multicolumn{5}{|c|}{ Cell number } \\
\hline & No damage & Low damage & Medium damage & High damage & Complete damage \\
\hline \multicolumn{6}{|c|}{ In the absence of metabolic activation factor } \\
\hline Control & $93 \pm 3$ & $3 \pm 3$ & 0 & 0 & 0 \\
\hline Curcuma aromatica & $70 \pm 3$ & $22 \pm 5$ & $8 \pm 4$ & 0 & 0 \\
\hline Curcuma zedoaria & $79 \pm 3$ & $15 \pm 2$ & $6 \pm 3$ & 0 & 0 \\
\hline Curcumin & $62 \pm 4$ & $28 \pm 3$ & $10 \pm 4$ & 0 & 0 \\
\hline \multicolumn{6}{|c|}{ In the presence of metabolic activation factor } \\
\hline Control & $97 \pm 3$ & $5 \pm 2$ & - & - & - \\
\hline Curcuma aromatica & $49 \pm 2$ & $24 \pm 5$ & $12 \pm 3$ & $6 \pm 5$ & 0 \\
\hline Curcuma zedoaria & $54 \pm 3$ & $30 \pm 1$ & $11 \pm 5$ & $5 \pm 4$ & 0 \\
\hline Curcumin & $41 \pm 3$ & $37 \pm 3$ & $10 \pm 2$ & $8 \pm 3$ & $4 \pm 3$ \\
\hline
\end{tabular}

Table 4: Mean Frequencies of Micronucleus observed in HEp-2 cells

\begin{tabular}{|c|c|c|c|c|}
\hline \multirow[b]{2}{*}{ Treatment } & \multicolumn{3}{|c|}{ Repetition } & \multirow[b]{2}{*}{$\begin{array}{c}\text { Mean } \pm \text { standard } \\
\text { deviation }\end{array}$} \\
\hline & 1 & 2 & 3 & \\
\hline \multirow{2}{*}{$\begin{array}{c}\text { Negative control } \\
\text { Positive control- in the absence of S9 factor }\end{array}$} & 6 & 3 & 4 & $4.33 \pm 1.086$ \\
\hline & & 32 & 35 & \\
\hline Positive control-in the presence of $\mathrm{S} 9$ factor & 25 & 28 & 24 & $25.666 \pm 1.555$ \\
\hline \multicolumn{5}{|c|}{ Curcuma aromatica salisb } \\
\hline In the absence of S9 factor & 13 & 15 & 09 & $12.333 \pm 2.223$ \\
\hline In the presence of S9 factor & 18 & 16 & 13 & $15.666 \pm 1.778$ \\
\hline \multicolumn{5}{|c|}{ Curcuma zedoaria (Christm.) Roscoe } \\
\hline In the absence of S9 factor & 8 & 9 & 12 & $9.666 \pm 1.999$ \\
\hline In the presence of $\mathrm{S} 9$ factor & 12 & 17 & 15 & $14.666 \pm 2.666$ \\
\hline \multicolumn{5}{|c|}{ Curcumin } \\
\hline In the absence of S9 factor & 14 & 17 & 13 & $14.666 \pm 1.555$ \\
\hline In the presence of $\mathrm{S} 9$ factor & 21 & 18 & 19 & $19.333 \pm 1.111$ \\
\hline
\end{tabular}


Several substances in plants express cytotoxic and genotoxic activities and show correlation with the incidence of tumors. Therefore, understanding the health benefits and or potential toxicity of the plants is important ${ }^{12}$. Although plant extracts have been used in the treatment of diseases according to knowledge accumulated over centuries, it is also known that many plants synthesize toxic substances, which in nature acts as defense against infections, infects and herbivores. Some substances present in some medicinal plants are potentially toxic and carcinogenic and it has also been reported that some traditional medicines may have genotoxic potentials. Assessment of the potential genotoxicity of traditional medicine is indeed an important issue as damage to the genotoxic materials may lead to critical mutation and therefore also to an increased risk of cancer and other disease. Major bioactive phytochemicals that have been associated with many plants are different types of saponins and flavonoid. In over all safety evaluation of the botanicals, a modest trend towards increasing the inclusion of information, a genotoxicity appeared in peak in the last four years because of significant awareness of the impact of genotoxicity ${ }^{17}$. In in-vitro assay, recent investigations have revealed that many plants used as food or in traditional medicine have mutagenic hazard $^{18}$. The isolated compounds from the plants such as Quercetin, furoquinoline, alkaloids and isothiocyanates were considered to be mutagens. It is very difficult to speculate the compounds that are responsible for mutagenic response detected with plant extracts because they are complex mixtures of organic compounds. Short term in-vitro and in vivo studies as well as long term carcinogenicity studies, with chemically treated animals confirmed that phytochemicals could also possess antimutagenicity and anticarcinogenic effect. Epidemiological studies also supported that the chemo preventive effect in which phytochemicals exhibit genotoxic/mutagenic effect by themselves or potential the effect of other xenobiotics ${ }^{19}$. Many literatures stressed the importance of carrying out the genotoxicity studies for the medicinal plants. Botanicals contain multiple chemical constituents which may be pharmacologically active with significant proportions of chemically undefined constituents, the genotoxic information obtained from studies using a whole herbal or multicomponent herb product is relatively lacking. The presence of phytoconstituents including tannins, catechins, flavonones, isoflavones are responsible for the possible genotoxic effects of plant extracts. Flavonoids inhibit topoisomerase I and II enzyme which will interfere with the replication and transcription process, inhibiting the relegation of DNA-double strand breaks and enhancing the formation of cleavable DNA- enzyme complexes. Phenolic rich extracts could lead to accumulated DNA breaks and mutation, thus contributing significantly to genotoxicity. Because of these above statement, a systematic phytoconstituents analysis has been carried out for Curcuma aromatica Salisb and Curcuma zedoaria (Christm) Roscoe. $50 \%$ hydro alcoholic extract of Curcuma aromatica salisb found to contain alkaloids, tannin and flavonoids where as Curcuma zedoaria (Chrism) Roscoe contain alkaloids and flavonoids. Total phenol and total flavonol content was found to be more in Curcuma aromatica than Curcuma zedoaria. The percentage of curcumin was found to be $6.14 \pm 2.13 \%$ and $3.84 \pm 1.76 \%$ for Curcuma aromatica and Curcuma zedoaria respectively. By any single genotoxic test procedure the mutagenic potential of an agent can't be reliably determined because currently available mutagenicity assays have their own strength and weakness ${ }^{9}$. Ames test is an in vitro mutagenicity assay which is useful for prescreening potential carcinogens, as approximately $80 \%$ of carcinogens are proved to be mutagenic ${ }^{9}$. In Ames test where the target organism is unable to oxidize chemicals, so necessary co factors must be supplied for an exogenous activation. The major group of chemical carcinogen is activated by S9, generally comprises the hepatic post-mitochondrial fraction from rats pre-treated with Aroclor 1254, a mixture of polychlorinated bi phenyl which serve as a potent inducer of cytochrome $\mathrm{P}_{450}$ families in particular $\mathrm{P}_{450} \mathrm{I}$ and $\mathrm{P}_{450}$ II. A clear mutagenic response is seen if the source of the liver preparation is obtained from Arclor 1254- treated animals. In the evaluation of genotoxicity of new chemicals, established mutagens are utilized as positive control to ensure not only the responsiveness of the bacterial strains but also the efficiency of the activating system during the routine employment of the Ames test. To mutate all Salmonella typhimurium strain 2- amino anthracene is most widely used mutagen which appears to be activated by hepatic system derived from all animal's species including man. Nhydroxylation catalyzes the activation of 2-amino anthracene since Aroclor 1254 is an established inducer of $\mathrm{P}_{450^{-}}$I family. The mutagenicity of 2-aminoanthracene was markedly decreased when the animals are treated with Arcoclor 1254. Microsome from the untreated animals could bioactivate 2amino anthracene to mutagens ${ }^{20}$. TA 98, TA 100 of Salmonella typhimurium are the histidine deficient (His") mutant tester strain. In many of the tester strain TA 98, TA 100 of Salmonella typhimurium does not have intrinsic potential to induce mutation by increasing the number of $\mathrm{His}^{+}$ colonies. Exogenous metabolic activation is required for most of the chemicals to form an ultimate mutagenic species to induce mutation in in- vitro assays including Ames Salmonella test. Some electrophilic chemicals are mutagenic and directly act with DNA. For metabolic activation studies, in general 4-5\% Aroclor 1254- inducer S9 fraction in the S9 mixture is used. In this study $1 \% \mathrm{~S} 9$ factor was used. To induce the mutagenic response, few chemicals require an elevated level of S9 fraction $10-30 \%$ in the S9 mixture ${ }^{10}$. Biological samples may cause problems in assays for mutagenicity using Ames test/ Salmonella test because of the presence of autxotrophic growth factors. In each of the colonies growing on the minimal agar plates, histidine added by biological samples to the test system may extend the autxotrophic growth phase of plated bacteria thereby increase the probability of spontaneous reversion to prototrophy. Histidine- related growth factors added in the plate incorporation test may give a false positive due to the consequence of extended autotrophic growth ${ }^{21}$. Some 20years ago, Ostling and Johnson developed the comet assay, which has its origin in the micro gel electrophoresis technique which can be performed in different ways and has been used for many different purposes during the last few years. By using the alkaline version of the assay it is possible to detect not only DNA single strand breaks and alkali labile sites but also DNA/DNA and DNA/Protein cross-links ${ }^{22}$. The assay which is capable of detecting the DNA damage in individual cells is the comet assay. At the time of lysis, increased DNA migration results from the induction of DNA- single strand breaks, alkali labile sites and incomplete excision repair sites cell death arising from a non- DNA mediated process or apoptosis is associated with increased DNA migration accompanied with DNA fragmentation. In extreme cases like the apoptotic cells, the head and tail are well separated and with an increasing number of breaks, DNA pieces migrate 
freely into the tail of the comet. Information about the number of strand breaks is provided by the intensity of fluorescence in the tail relative to the head. Over the wide range of damage, tail length, percentage of total DNA in the tail and tail moment all reflect DNA damage, though the percentage tail DNA generally seems to be most useful. A measure of both the smallest detectable size of migrating DNA which is reflected in the comet tail length and the number of relaxed/broken pieces which is represented by the intensity of DNA in the tail is incorporated in the tail moment. Inter individual differences such as the age of blood donors and their physical activities, smoking habit and cell cycle status are important and may reflect differences in the repair of an induced DNA damage likely to add complexicity to the problem. During comet formation in both alkaline and neutral assay system, the chromatin structure which is fundamental to the replication and transcription activity affects the role of DNA ${ }^{23}$. Among the three tested compounds Curcumin was found to be more genotoxic in nature when compared by Curcuma aromatica, Curcuma zedoaria. These results might either due to the presence of low concentration of Curcumin in the extracts or due to the presence of other phytoconsituents that are present in the extract. The damage of the cells was found to be less in the absence of metabolic activation factor than the presence of metabolic activation factor. This confirms the original parent molecule is not genotoxic in nature but its metabolites are producing the genotoxicity effect in various models.

\section{Micronucleus test}

A micronucleus test is a test used in toxicological screening for potential genotoxic compounds. The assay is now recognized as one of the most successful and reliable assay for genotoxic carcinogens, i.e carcinogens that act by causing genetic damage and is the OECD guidelines for the testing of chemicals. There are two versions of this test; one is in vivo and other in vitro. A micronucleus is the erratic (third) nucleus that is formed during the anaphase of mitosis or meiosis. Micronuclei are cytoplasmic bodies having a portion of acentric chromosome or whole chromosome which was not carried to the opposite poles during the anaphase. Their formation result in the daughter cell lacking a part or all of a chromosome. These chromosome fragments or whole chromosomes normally develop nuclear membrane and forms as micronuclei as a third nucleus. After cytokinesis, one daughter cell ends up with one nucleus and the other ends up with one large and one small nucleus, i.e., micronuclei. There is a chance of more than one micronucleus forming when more genetic damage has happened. The micronucleus test is used as a tool for genotoxicity assessment of various chemicals. For the safety evaluation of new drugs or industrial chemicals in Japan as well as in other countries, the micronucleus test has been widely used as a sensitive in vivo genotoxicity test and has been recommended for use in regulatory guidelines. From guidelines to guidelines, the experimental protocol of the test varies slightly in details such as number of animals, sex, dosing and sampling time. Before the start of full scale experimentation, a pilot preliminary experiment was to be carried out for each test substances because the optimum response may vary according to the chemical concerned ${ }^{24}$.

\section{CONCLUSION}

Among the three tested compounds curcumin produced the higher genotoxic effect in all the tested models. Among the plant extracts, Curcuma aromatica showed more genotoxic effect than Curcuma zedoaria but when compared to the positive control the genotoxic effect was found to be very very less and it was almost similar to that of negative control. This confirms that Curcumin alone in the presence of metabolic activation factor produced genotoxicity in somewhat higher amount than its absence.

\section{ACKNOWLEGEMENT}

Authors would like to thank JSS Mahavidyapeetha, Mysore and JSS College of Pharmacy, Udhagamandalam for providing the infra structure for the successful completion of this project.

\section{REFERENCES}

1. Ammayappan rajam Srividya, Sangai Palanisamy Dhanabal, Vaithiyalingam Jagannathan vishnuvarthan. Mutagenicity/ Antimutagenicity of plants extracts used in traditional medicine: A Review. World Journal of Pharmacy Research 2012; 2(1): 236-259.

2. Srividya AR, Dhanabal SP, Sathish Kumar MN, Vishnuvarthan VJ. Genotoxic activities of hydro alcoholic extract of Curcuma aromatica Salisb, Curcuma zedoaria and Curcumin by chromosomal aberration test. International Journal of Biotechnology 2013; 111: 145-160.

3. Naglaa M Ebeed, Halima S Abdon, Hoda F Booles, Sherifa H Salah, Ekram S Ahmed, Kh Fahny. Antimutagenic and Chemo prevention potentialities of Sweet fennel (Foeniculum vulgare Mill) Hot water crude extract. Journal of American Science 2010; 6(9): 831-842.

4. Srividya AR, Dhanabal SP, Sathish Kumar MN, Vishnuvarthan VJ. Genoprotective activity of hydro alcoholic extract of Curcuma aromatica and Curcuma zedoaria rhizomes and their comparison with Curcumin. Journal of Ethnobiology and traditional Medicines. Photon 2013; 118 : 306-321.

5. Ansari SH Ahmed, Ansari S, Ansari F, Ali SH, Bhat MD. Phytochemical and biological Investigation on Curcuma aromatica: A Review. Pharmacognosy Reviews 2009; 2(3): 244-229.

6. Khare CP. Indian Medicinal Plants- an Illustrated dictionary. Springer science: business media LLC; 2007.

7. Srividya AR, Dhanabal SP, Sathish Kumar MN, Vishnuvarthan VJ. Relationship between Curcumin and antioxidant activity in Curcuma aromatica and Curcuma zedoaria rhizomes. Journal of Free radicals and antioxidants. Photon 2013; 139: 186- 198.

8. Anderson D and Plewa MJ. The International Comet assay Workshop. Mutagenesis 1998; 13: 67-73. http://dx.doi.org/10.1093/mutage/13.1.67 PMid:9491397

9. Ann J Dunipace, Rebecca Beaver, Timothy Noblitt, Yiming Li susam aunt and George Stokery. Mutagenic potential of Toludine blue evaluated in the Ames test. Mutation Research 1992; 279: 255-259. http://dx.doi.org/10.1016/0165-1218(92)90241-Q

10. Meshram GP, Padma Malini R and Kola M Rao. Mutagenicity of N, Ndimethylurea and methylamine hydrochloride in the Ames Salmonella/microsome test; absence of mutagenic response. Mutation Research 1992; 279: 275-280. http://dx.doi.org/10.1016/01651218(92)90244-T

11. Rebai Ben Ammar, Mohamed Ben Sghaier, Jihed Boubaker, Wissem Bhouri, Aicha Naffeti, Ines Skandran, Ines Bonhlel, Soumaya Kilani, Kamel Ghedira, Leila Chakir- Ghedira. Antioxidant activity and inhibition of aflatoxin B1-nitrofuroxazide and sodium azide- induced mutagenicity by extracts from Rhamuus alaternus L. Journal of Chemico-Biological interactions 2008; 174: 1-10.

12. Yen CG, Chen MY and Peng HH. Evaluation of Cytotoxicity, Mutagenicity and antimutagenicity of merging edible plants. Food and Chemical toxicology 2002; 39: 1045-1053. http://dx.doi.org/ 10.1016/S0278-6915(01)00053-9

13. Ines Skandrani, Jihed Boubaker, Ines Bouhlel Ilef, Linen, Kamel Ghedira, Leila Chekir- Ghedira. Leaf and root extracts of Moricandia arvensis. Protect against DNA damage in human lymphoblast cell K 562 and enhance antioxidant activity. Environmental Toxicology and Pharmacology 2010; 30: 61-67. http://dx.doi.org/10.1016 /j.etap.2010.03.014 PMid:21787630

14. Demma J, Engidawork E, Hellman B. Potential genotoxicity of plant extracts used in Ethiopian traditional medicine. Journal of Ethno pharmacology 2009; 122: 136-142. http://dx.doi.org/10.1016 /j.jep.2008.12.013 PMid:19146933

15. Miyaji CK, Poersch A, Ribeiro LR, Eira, AF, Colus IMS. Shiitake Lentinula edodes Berkeley Pegler extracts as a modulator of micronuclei induce in HEp-2 cells. Toxicology in-vitro 2006; 20: 1555-1559. http://dx.doi.org/10.1016/j.tiv.2006.07.004 PMid:16949247

16. Santos FV, Colus IMS, Silva MA, Vilegas W. Varanda EA. Assessment of DNA damage by extracts and fractions of Strychnos pseudoquina, A Brazilian medicinal plant with anti-ulcerogenic activity. Food and 
Chemical toxicology 2006; 44: 1585-1589. http://dx.doi.org/10.1016 /j.fct.2006.03.012 PMid:16730111

17. Kuei-Meng Wu, Jinhni Dou, Hanan Ghantous, Shaw Chen, Anita Bigger, Debra Birukrant. Current regulatory perspectives on genotoxicity testing for botanical drug product development in the U.S.A. Regulatory toxicology and pharmacology 2010; 56: 1-3. http://dx.doi.org/10.1016/j.yrtph.2009.09.012 PMid:19782117

18. Esameldin E, Elgorashi J, Pslyn Taylor LS. Annemarie Macs, Johanner Van Staden, Norbert De, Kimpe Luc Verschaeve. Screening of medicinal plants used in South African traditional medicines for Genotoxic effects Toxicology Letters 2003; 143: 195-207. http://dx.doi. org/10.1016/S0378-4274(03)00176-0

19. Volker Mersch-Sundermann, Theeshan Bahorum, Thorstenstaue, Vidushi S Neergheen, Mohammed A, Soobrattee, Robert Wohlfarth, Rosa Sobel, Hubertus E Brunn, Tim Schmeifer, Evelyn lamy, Okezie I Aruoma. Assessment of the DNA damaging potency and chemo preventive effects towards Bap- induced genotoxicity in Human derived cells by Monimiastrum globosum, an endemic Mauritian Plant. Toxicology In- vitro 2006; 20: 1427-1434. http://dx.doi.org/10.1016 /j.tiv.2006.06.014 PMid:16934955

20. Ayrotons AD, Neville S and Leannides C. Cytosolic activation of 2aminoanthracene implication in its used as diagnostic mutagens in the Ames test. Mutation research 1992; 265: 1-8. http://dx.doi.org/10.1016 /0027-5107(92)90034-Y
21. Lars Nylund and Pirkko Einisto. Mutagenicity testing of protein containing and biological samples using the Ames test/Salmonella plate incorporation test and fluctuation test. Mutation Research 1993; 272: 205-124.

22. Maria Anderson, Eva Agurell, Hamid Vaghef, George Bolcsfoldi Bjorn, Hellman. Extended-term culture of human T- lymphocytes and the comet assay; a useful combination when testing for genotoxicity in vitro. Mutation research 2003; 540: 43-55. http://dx.doi.org/10.1016/S13835718(03)00169-4

23. Ruzica Rozgaj, Vilena Kasuba and Aleksandra Fucic. Genotoxicity of Cadmiun chloride in human lymphocytes evaluated by the comet assay and cytogenic tests. Journal of trace elements in medicine and biology 2002; 16: 187-192. http://dx.doi.org/10.1016/S0946-672X(02)80024-4

24. Hiroyasu Shimada, Sachiko Satake, Satorn Itoh, Chiharm Hattori, Makoto Hayashi and Motoi Ishidate. Multiple dosing effect of Benzo[a]pyrene in mouse bone marrow micronucleus test. Mutation research 1990; 234: 171-181.

Cite this article as:

Srividya A.R, Dhanbal S.P, Sathish Kumar M.N and Vishnuvarthan V.J. Comparison of genotoxicity produced by hydro alcoholic extract of Curcuma aromatica Salisb, Curcuma zedoaria with Curcumin by Ames test, Comet assay and Micronucleus test. Int. Res. J. Pharm. 2013; 4(6):113-119 